\title{
DID AUGUSTINE'S CHRISTOLOGY DEPEND ON THEODORE OF MOPSUESTIA?
}

\author{
JOHN McGUCKIN \\ Department of Theology, University of Leeds
}

There has been considerable controversy over Augustine's Christology throughout this century, concerning the attribution of sourçes, and whether he ought to be characterized as Antiochene or Alexandrian in his general approach - that is, whether he prefers a dynamic grace-centred model of the Christological union, such as that of Theodore and Nestorius, or whether he envisages a more substantial root of the union such as that argued by the language of hypostatic union of Cyril and Chalcedon. This article will review some aspects of that issue and attempt to elaborate a perspective from which to approach his Christology. It is not intended here to expose the whole complex range of Augustine's doctrine of Christ; it will be enough to point out significant areas of its development. Several excellent studies have already treated this dimension, 'although Augustine's far-ranging complexity on this subject, as on most, makes the issue a wonderful research ground for further work. Even the casual reader of Augustine on this subject realizes just how much his emphasis on the redemptive humility of Christ provided the spur and context of Barth's monumental Christology. Moreover, Augustine's special emphasis on an ecclesiological Christology (the totus Christus approach in which he joins in a symbiosis his thoughts on the person of Christ and the destiny of the saints of Christ who are his body) makes him stand apart in the lists of the patristic giants, a brilliant interpreter of the later Pauline Christology.

Unlike other aspects of Augustine's thought his Christology was not battled out in the heat of controversies. Even so, all the major controversial elements of his life - the Manichean conflict, the early acceptance of Neoplatonism, the Donatist issue, the appearance of the Arians in Africa, and finally the Pelagian crisis - all left significant marks on his Christology of the relevant periods. Here I wish mainly to consider his writings in Africa after AD 412 when his thoughts on grace and merit had been sharpened by Pelagianism, and when these issues begin to rise to the surface in his 
Christological reflection. The discussion has particular relevance for the modern Chrisological debate which has reopened many of the old arguments.

\section{THE CONTROVERSY OVER AUGUSTINE'S CHRISTOLOGY}

In the late nineteenth century investigation into Augustinian Christology was revitalized by Augustus Dorner and Adolf Harnack. ${ }^{2}$ Both scholars brought to the forefront Augustine's frequent use of phrases in his writings which spoke of the presence of God in Christ by grace, and of 'the man assumed by the deity', terms preferred by the Antiochene school of theologians of the fifth century, rather than the Alexandrian tradition reflected at Ephesus in 431 and triumphant at Constantinople II in 553. Both scholars observed that it was characteristic of Augustine to regard the act of assumptio which constituted the incarnation of the Word as a Trinitarian actus rather than a movement proper to the Logos alone ${ }^{3}$ - a perspective which had frequently been presumed by the earlier tradition. As a result, Dorner and Harnack argued, the uniqueness of Jesus for Augustine could no longer be posited along the lines of a profound and unrepeatable localization of the Word in him, and if this uniqueness were to be preserved it had to be reargued on the basis of a singular receptivity in Christ to the presence of God. To summarize very crudely: if this were so, Augustine would be rejecting concrete terms for the Christological union and preferring the dynamic category of relationship (a thematic insight so prevalent in his De Trinitate). In short he would be in the camp of Eustathius of Antioch, Theodore of Mopsuestia, and Nestorius of Constantinople, who described the union of the divine and human in Christ as a correlation on the basis of grace (бuvá $\left.\varphi \varepsilon i \alpha \kappa \alpha \tau^{\prime} \varepsilon u j \delta o \kappa i ́ \alpha v\right)$ and who stressed the separateness of those factors that stood in relationship by their formula, 'the man assumed by God'.

This, not unexpectedly, came as quite a shock to the world of Catholic scholarship of the period, which had canonized Augustine as the supreme doctor of the Catholic tradition and found it inconceivable that on such an important matter he could ever be found in the same bath-tub as Nestorius. The surprise on this front was indicative of two facts: firstly, that Augustine's Christology had been, in the main, passed over on the presumption that he simply agreed with Leo, which is only partly true; and secondly, that the neoscholastic method of Catholic theology prevalent at that period had over-rigidly classified areas of theological enquiry in its methodological approach, leaving it particularly ill-prepared to attain a clear perspective.

The scholastic habit of beginning dogmatics with De Deo uno before moving on to De Deo trino ran counter to Augustine's systematic process, and the tradition of separating the treatises De persona Christi and De gratia not 
only made it difficult for the world of Catholic scholarship to appreciate Dorner's and Harnack's remarks, but even to enter into the correct exegesis of Augustine's Christology itself, within its own historical context and on his own terms.

In 1901 Otto Scheel published a monograph ${ }^{4}$ attacking and reversing Dorner's and Harnack's conclusions, and this was taken up substantially in subsequent Catholic analyses. In $1902 \mathrm{E}$. Portalié composed the article on Augustine for the Dictionnaire de Théologie Catholique (published in English translation in 1960$)^{5}$ depending on Scheel's results. The initial premiss of Portalié's enquiry is to presume that there had been a smooth and progressive evolution of an 'orthodox' line on Christology, enduring stable throughout all heretical vagaries, and that Augustine is a representative of that line. As a result, he makes bold claims and outraged remarks on behalf of Augustine's Christology:

On no other point of revelation is the teaching of Augustine clearer, or more constant, or more logically connected. On no other point, similarly, have the Protestant critics made such sorry efforts to draw him away from orthodoxy and relegate him to either Docetism or Nestorianism.

But when Portalie comes out from his 'rhetorical mode' to analyse the actual Christology of Augustine, he again approaches it in the neorscholastic manner under anachronistic headings such as 'The perpetuity of the hypostatic union', and this is a method which seriously undermines the critical value of his study. It is perhaps sadder to see denominationalisms still operative in present-day Catholic scholarship, but that is what seems to emerge in the recent continuation of the Quasten Patrology in the monograph on Augustine by Agostino Trape ${ }^{6}$ of the Augustinianum. The tone of this study (Italian 1978, English translation 1986) is breathlessly hagiographic throughout, and an innocent reader would gain no idea from his text that there ever had been a controversy over aspects of Augustine's Christology. Trapè suggests that his doctrine in this instance is "distinguished from traditional teaching only by the clarity of its language" and, like Portalié before him, he proceeds to analyse the structure of the Christology in terms which attempt to parallel it with the central issues raised at Chalcedon - an entirely anachronistic and distorting procedure.

It was in fact to the credit of TeSelle. in 1970, that the controversial iscue of the Christology was reopened in a fruitful way. On the basis of the more balanced and critical monograph on Augustine's Christology by Tarsicius van Bavel in $1954,{ }^{8}$ TeSelle was able to conclude that in spite of many minor inaccuracies and distortions of emphasis on the part of Dorner and Harnack, their overall feeling that Augustine was more in line with Antiochene Christology than Alexandrian, was substantially correct. In speaking of this 
'Antiochenism' TeSelle goes on to say:

This, I think, is the actual character of Augustine's Christology. Doubtless it is not the only Christology of the early Church. But a strong case can be made that it was the Christology generally assumed to be true during the first few centuries until it appeared to have been condemned as adoptionism . . . in the affair of Paul of Samosata. But during a crucial period in the development of doctrine, the period between the condemnation of Apollinarianism about 380 and the Council of Ephesus in 431, it came to constitute the main line of development, until once more it fell under suspicion as too close to Nestorianism.

Leaving aside for the moment the question whether TeSelle's Dogmengeschichte is correct (and it seems to owe too much to Walter Bauer), the point he made about the 'overall' character of the Christological thrust in Augustine brought the issue back onto the agenda. More recently, in 1979, Joanne McWilliam Dewart published a study ${ }^{10}$ developing TeSelle's thesis, and arguing in addition a direct textual dependence of Augustine on the $D e$ Incarnatione of Theodore of Mopsuestia written in 391. ${ }^{11}$ Before considering this in greater detail it may clarify matters if we briefly consider the salient points of Augustine's doctrine of Christ in terms of the major developmental stages through which it evolved.

\section{THE NATURE OF THE CHRISTOLOGY}

Augustine's Christology seems to evolve in three clear stages. It was an intellectual evolution that did not need to be forged in the exigencies of any apologetic as was the case with his later doctrine of grace and predestination. This is surely a factor which makes the development of his Christology all the more interesting for us and sets it as a more accurate indicator of the state of Western tradition at that period.

Augustine knew of Photinianism, an Arian form of Christological adoptionism, through Ambrose who had been an imperial administrator in Sirmium when Photinus himself was in residence in the city after the emperor Julian's recall of heterodox exiles. In the Confessions Augustine was even able to identify his youthful self retrospectively as a crypto-Photinian; ${ }^{12}$ but that position was certainly not his from the time of his return to Africa from Milan, nor was it a position that had any current representation in the African Church. Both Augustine and his close friend and colleague Alypius were from the outset convinced of the basic and simple reality of the full range of Jesus's human life, and neither had any inclination to positions such as Apollinarism which elaborated a limited Christological union on the basis of a diminished sense of the real manhood of Jesus. ${ }^{13}$

Augustine had first-hand experience of Arianism later in his ministry in 
the form of the German auxiliaries who garrisoned Hippo Regius under Boniface, Count of Africa, but his apologetic writings in this context all reflect the reality that in the fifth century, up to the time of the Vandal invasions, Arianism was a spent force in the African Church - a religion of foreign barbarians. Augustine defends the Nicene orthodoxy with the sense of assurance that this is a wholly established position. In his treatment he follows Hilary, Marius Victorinus and Ambrose, all of whose texts he has read, and he advances on them to the extent that he labours to remove the last trace of 'subordinationism' in his Trinitarian thought, a movement that perhaps had a not wholly beneficial result on subsequent theological development.

The Donatist crisis in which Augustine was embroiled did not turn around Christology at all. The only arguable effect it can be posited as having on his doctrine was perhaps to deepen the ecclesial base of his Christology. He learned from Tyconius, the great Donatist lay theologian, his rules of exegesis, the first of which (De Domino et corpore eius) maintained that scripture habitually makes no distinction between Christ and his body, the Church, as both are bound together as one mystery. This aspect of Augustine's thought has been typified under the title, 'totus Christus' Christology. In other words, he is greatly influenced by the Pauline schema of Christ as head over many members. ${ }^{14}$ There is no clear line in Augustine's Christology between Christ understood as an individual historical locus and Christ as a mystical summatio - it is an aspect of Augustinian thought which Barth will later reinvent. This approach gives Augustine's whole Christology a breadth and coherence that resists any reductionist approach, sadly so common in patristic commentators, that seeks to break it down into decontextualized formulae. Augustine never had to produce any new technical definitions, and this is why his Christology is expansive and resists neat classification.

The last great controversy of Augustine's life was Pelagianism. Again Christology as such was not the central bone of contention here, but in so far as his thoughts on the nature of grace and election were greatly sharpened by the dispute with Caelestius, Pelagius and Julian of Eclanum, one can trace in the writings of this period a clear effort on his part to connect the two areas of his reflection, and he begins to speak of Christ as the perfect example of the man endowed with the prevenient and unmerited grace of God. It is precisely at this point that he seems to have lines of connection with the Antiochene school represented by Thcodore and Nestorius.

Like so much in his work, Augustine's Christology evolved in stages. His first writings follow the traditional Latin emphasis found in Tertullian, Minucius Felix and Lactantius, which concentrates on the pedagogic role of Christ. The early writings of the period after his conversion, such as the Christology of the De magistro or the De vera religione (390), depict Jesus 
as a somewhat remote exemplar of virtuous living, and later were to exert a fascination on Abelard.

A second stage of development can be discerned in his writings after ordination in 391 . He requested time from his consecrating bishop, Valerius, before undertaking liturgical duties which included most of the preaching in the Hippo Church, to embark on a protracted study of the scriptures. This clearly bore fruit for the following year. In his Expositions (Enarrationes) on the first thirty-two psalms a new sense of the saving role of Christ's human life emerges. Here he depicts the Christ of the psalms as praying to God as follows: 'To you Lord I cry: My God do not separate the unity of Your Word from that which as man I am . . for since that which is of the eternity of Your Word unites itself uninterruptedly with me I am not such a man as others are who are born into the deep misery of this world'. ${ }^{15}$ We may note here that the concept of the uninterrupted mutual presence of the divine and human in Christ, in terms of a reciprocal indwelling in the soul, is what Eustathius of Antioch, the teacher of Theodore of Mopsuestia, had adopted as his preferred mode of Christological discourse. ${ }^{16}$

It is in these commentaries on the Psalms that the idea of the centrality of the soul of Christ first appears in Augustine's work. He uses the notion of the closeness of the body-soul relationship as a favourite analogy for the terms of the Christological union. In the case of the composition of a man, spirit is joined with flesh - two very disparate elements indeed, yet they make up an intimate whole. In the case of Christ, however, an easier and deeper unity occurs. Spirit joins with spirit: the Word of God unites himself to the soul of Christ, a union of close compatibles which constitutes the possibility of the enfleshment of God - anima mediante, through and by the soul's mediation. This doctrine is elaborated in the famous Letter 137 to the pagan Senator Volusianus, then Proconsul of Africa and later Prefect of Rome.

In the sermons of this period. Augustine speaks of the assumption of a man (hominem suscipere), ${ }^{17}$ but at one and the same time he witnesses a straightforward acceptance of what could be classified 'ontological' Christology - that is, the attempt to found the Christological union on a more substantial category than relationship, symbolized in Cyril of Alexandria's preferred terms for the union, i.e., physis and hypostasis. In AD 395, for example, Augustine draws a clear distinction between Christ and other men who do not happen "to have naturally the "person" of Wisdom (naturaliter habere personam sapientiae)'. ${ }^{18}$ And again in the De Trinitate, a section written between 413-416, he returns to this radical distinction: 'The Word in man is one thing, the Word made man is another'.

Augustine is the heir to a long-standing Latin tradition in Christology which had, from the time of Tertullian and Novatian in the third century, elaborated 
technical terms and formulae to express its insights. From Tertullian he repeats the classic formula of the unity of person in a duality of substances. ${ }^{19}$ In $\mathrm{Ser}$ mon 294 he shows the extent to which he presupposes this when he defines the Christological union as: 'One person made firm from two substances; one person in either nature'. ${ }^{20}$ From Novatian he repeats, and abundantly uses, the principle of the distinction of operations in Christ: He does some things as God, others as man - qua Deus, qua homo - a schema followed equally by Lactantius, Marius Victorinus, Ambrose and Rufinus of Aquileia. Within the framework of this traditional Christology Augustine uses the 'one person' language vividly and frequently throughout his sermons: 'He who is man is the very one who is God; and not by confusion of natures but by the unity of the person'. ${ }^{21}$ Such a synopsis of Christology appears also in the Enchiridion ad Laurentium of 421 and right at the very end of his life in the De praedestinatione sanctorum of 429 - which suggests that the stages of Augustine's Christological development ought not in any way to be seen as mutually exclusive.

Would it be accurate, then, simply to call Augustine a traditionalist Latin in his Christology, and be done with it? One thing in particular should make us hesitate in this regard. This is not his regular use of the phrase 'the assumed man' (assumptus homo), which as H.M. Diepen has demonstrated, ${ }^{22}$ is a formula that runs unproblematically through patristic thought up to the fifth century; it is rather a distinctive new emphasis that appears in his writing after the Roman refugees come to Africa in the aftermath of Alaric's sack of the city in AD 410. This new strand of thought is the notion that the Christological union was itself a grace, and it is a theme which we could even call the third and most distinctive stage of the evolution of Augustine's Christology.

The notion first appears in 412 , the year after Caelestius had first raised the issues of grace and merit in Carthage, and had been synodically condemned for his pains. In his treat ise On the Merits and Remission of Sins of that year, Augustine appeals to Christ as the supreme example of unmerited antecedent grace:

Pride is the cause of all human offences. For its condemnation and removal a great heavenly medicine comes. The humble God descends in mercy, displaying to man puffed up by pride, clear and obvious grace in the very man he took to himself with a great love beyond his fellows. For although he was conjoined

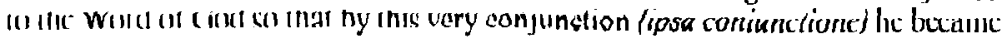
at one and the same time the unique Son of God and, the same one, the Son of Man, even in his case he did not act by the antecedent merits of his own will. He had, no doubt, to be unique. Could it be possible for there to be two or three or more (Christs)? If so, it would not have been from God's gift but from man's free will and choice. ${ }^{23}$ 
Although this last phrase is obscure, what Augustine is arguing is that the antecedent free grace of God operative in the Christological union is the single fundamental power which reserves the 'uniqueness' of Christ to the deity. If, on the other hand, human merit could achieve union with God from its own efforts or on its own terms, there could, theoretically, be more than one Christ - a possibility Augustine rejects as absurd, thereby concluding that the antecedent power of God's grace is the definitive proprium of Christological uniqueness.

This new emphasis is brought to a peak in his celebrated Letter 187, On the Presence of God. This text was written in AD 417 at the height of the Pelagian controversy, when Pope Innocent had acceded to African demands to confirm at Rome the African condemnation of Pelagius and Caelestius. Almost immediately after this decision Innocent died, and his successor Pope Zosimos held back from a condemnation, having been favourably impressed by a libellus fidei sent to him from Pelagius in Palestine. The African hierarchy under the leadership of Aurelius of Carthage and Augustine himself, had appealed to the Emperor Honorius directly at Ravenna and so forced Zosimos' hand that he had to accede to the condemnation, like it or not. This precipitated a revolt of eighteen Italian Bishops, including Julian of Eclanum who regarded the whole matter as a blatant attempt of the African Church to impose dubious theologoumena on the Latin tradition as a whole. It is in this context, therefore, at a time which must have seemed a high point in the fortunes of the African Church that Augustine composes this text which was to have such a profound influence for centuries to come.

In Letter 187 Augustine elaborates a doctrine of degrees of presence. God is present totus ubique: entirely and everywhere, without discrimination. He is present to all things in existence, giving form, but dwells in, or inhabits, only beings which have understanding and volition. These he indwells only to the extent that they are 'with him', that is, orientated towards him with love and atiention. ${ }^{24}$ Augustine maintains here that God dwells only in those who are influenced by his grace, ${ }^{25}$ and they take hold of him (capere) to a greater or lesser degree according to their readiness. Using Colossians 2:9 he describes how 'in Christ the fullness of the godhead dwells bodily'. This he argues cannot be taken to mean 'materially' but rather that Christ is the head and sum of what is represented in the saints, who are his body. Although the Christological union is unique, it is effected by grace just as much as the indwelling of God in other men - only more so, for here there is a 'singular grace' of assuming him into a unity of person with the Word. ${ }^{26}$ 


\section{THE ATTRIBUTION OF SOURCES}

On the basis of Letter 187 in 1979 Joanne McWilliam Dewart categorized Augustine as not only Antiochene in persuasion but directly dependent on the work of Theodore of Mopsuestia. She makes a general synopsis of the argument in her words:

(In Letter 187) he argues that God is present to Christ not substantially nor by operation, but by love and grace, and that this gracious presence differs from the divine presence to the just in general in its fullness and because it brings about a personal union between the Word and the man in Christ. ${ }^{27}$

Dewart's thesis may be characterized, therefore, as having two parts (beyond the obvious and undisputed point that here in Letter 187 is a Christology based on the notions of grace and love). The first is a radical distinction she wishes to draw between 'substantial presence' and 'grace-presence'. The second is that this view is dependent quite specifically on Augustine's reading of Theodore's treatise De Incarnatione before he composed his Letter 187. I would suggest that both inferences are mistaken.

In the first place all the protagonists in the East knew that the Christological union could never be posited on the basis of the term ousia (substance or essence). It was an old chestnut to accuse one's enemies of having fallen into this folly, but no one seriously argued it either in the late fourth century or the fifth. The battle turned around the legitimate employment of other terms to posit union, such as physis and hypostasis - terms signifying concretization and quality but not essence. As Jerome found out the hard way, trying to make sense for the West of the new use of hypostasis in the Trinitarian solutions of the late fourth century, a new and hard line had emerged in the East between the legitimate application of ousia and other qualitatives such as hypostasis and physis. This was not immediately apparent to the Western theologians who had traditionally bothered to make little distinction between substantia and natura, and who had the alarming experience of initially misreading the Eastern theology of three hypostases in God as being synonymous with three naturae, hence tritheistic. Nonetheless, in the central matter in hand, the Latin tradition after Tertullian was no less certain than the East that neither substantia nor natura could ever, in any circumstances, be used to depict the Christological union. The unitive term was unquestionably, and strictly, persona.

So if we are to make any sense of a thesis that supposes an Augustinian rejection of 'substantial unity' it is clear that we need to clarify the terms of the argument much more precisely. What seems to be the issue, in other words, is whether Augustine elects an ontologically based union or a dynamic, gracecentred model - a moral union. The simple fact of the matter is that he prefers 
both approaches, and does not see them as mutually opposing, an insight that was sadly missed at Ephesus in 431 and 449 . The fact that he does not see the categories of 'substantial' and 'graceful' as mutually opposing descriptors in the Christology debate can be confirmed by the way in which four years after his Letter 187 he writes a synopsis of Christology in the Enchiridion which returns wholesale to the terms of the traditional Latin settlement.

Dewart argues that Augustine deliberately parts company with Gregory Nazianzen's Letter to Cledonius ${ }^{28}$ over this matter:

In this case [Augustine] rejected the very mode of union that Gregory had opted for, substantial (kat'ousian), and adopted the one he had rejected, by grace (kata charin) (Ep.101, PG.37.180). It is against this background that I suggest that Letter 187 be compared to Theodore's Treatise on The Incarnation. ${ }^{29}$

This, I suggest, is a misreading of Gregory's point, with a concomitant misreading of Augustine's intention: for Gregory does not speak here of a 'union on a natural basis' (kat' ousian), which would be a nonsense as he himself has just argued, berating the Apollinarists for either introducing a fourth into the Trinity or for making the God-man into a new ousia of union, thus neither God nor man but some strange new hybrid. What Gregory argues in Letter 101, deliberately and quite precisely, is a ouvá $\varphi \varepsilon 1 \alpha \kappa \alpha \tau^{\prime}$ oủoíav a correlation of natures; $;^{30}$ and anyway his purpose at the point cited is not to elaborate the terms of the Christological union, but rather to rule out of court adoptionist prophetic Christology which sees the deity working in Christ in the same way as it raises up prophets. This latter implication Augustine is just as concerned to avoid, and in section 40 of Letter 187 he argues as follows:

It is clear that by this unique assumption of the man he is made one person with the Word. For it has never been, nor is it, nor will it ever be, possible to say of any of the saints: And the Word was made flesh. None of the saints by any excellence of grace of any kind ever received the name of Only Begotten.

Augustine, then, is using the images of grace and inhabitation but not exclusively so in the way Dewart seems to suggest. His point is not to reject an ontologically founded Christological unity - indeed this is just what is implied by the fifth-century philosophical conception of in una persona; ${ }^{31}$ rather his treatment at this point in the Letter is preoccupied with demonstrating the exegetical nicety that 'the fullness of the deity dwelling bodily' (of Colossians 2:9) does not imply that God's presence is a material entity. ${ }^{32}$

When Augustine speaks of a union in una persona he does not mean that the psychological human subject Jesus of Nazareth has been absorbed in or replaced by the subject of the Word of God. He does not use 'person' in this psychological sense. In modern thought the term 'person' refers to an 
individual rational identity. For Augustine it meant straightforwardly a principle or a function of the unity of separate elements. In its functional usage Augustine speaks of Jesus 'in his person as a priest ' $;{ }^{33}$ in its unitive usage it was applied in the long-standing debate in ancient philosophy over the nature of 'composites'. For example, in the composite of human nature, according to fifth-century psychology, personal unity joins together a soul and flesh. To be a human person is to have this kind of psychosomatic unity. In the case of Christ, Augustine is arguing that he has this kind of unity in so far as he is truly a man, but that he also has a higher principle of unity in his being, for the composite of soul and body of Christ is further united or more profoundly integrated with the Word. There is, then, a threefold composite of Word, soul and body. The person of Christ means the union of divine and human natures. Augustine puts it simply: 'Just as any man unites in one person a rational soul and body, so Christ unites in one person the Logos and a man'.34

Dewart proceeds in the second part of her thesis to tie the connecting lines between Augustine and the Antiochenes even more tightly by postulating a direct literary dependence of Letter 187 on Theodore's De Incarnatione. To support this she cites seven instances of parallelism. ${ }^{35}$ In none of them can I find any synonymity of language, only the commonality of the theme of God's presence in the saints. At several instances of supposed parallel Augustine is clearly elaborating his argument from the basis of biblical allusions which are not present in Theodore. If there had been a literary dependence, biblical paradigms might well have been omitted but hardly added in the way they appear in Augustine's text - closely woven into the fabric of his argument. Moreover it is very questionable indeed whether Augustine was able to read Greek fluently by 416 , and there is no evidence to suggest that Theodore's work was circulating in Africa in Latin translation by that date. Dewart's two supportive arguments in this respect are extremely weak. ${ }^{36}$ The first, that 'Theodore was highly esteemed in the East and as likely as any to be translated', is not worthy of consideration; and the second, that 'We also know that he (Theodore) was popular at a later date in North Africa', is beside the point. This refers to Facundus of Hermiana who knew a Latin version of Theodore in AD 548. But the Three Chapters controversy explains the dissemination of his works in the West at that period.

III rati. III aillitarily al Ineme can be explained withuut recourse io all Antiochene thesis at all. The doctrine of the degrees of presence is a concern that exercised Plotinus and Porphyry generally to the point of being a topos of the Neoplatonic school. Marius Victorinus' own Christology pays great attention to the question, ${ }^{37}$ and Hadot's critical study has shown that the concept of the incorporeal within the sensible is a distinctive mark of all 
Victorinus' thought. We are led to conclude, therefore, that it is from the writings of Porphyry mediated to him through the Christian circle of Victorinus, Simplicianus the priest, and Ambrose, that Augustine gained the seed of his ideas that was later to blossom in Letter 187, On the Presence of God.

\section{CONCLUSION}

This article began with a controversy over how 'orthodox' or how traditional Augustine was in his Christology. The key conclusion that emerges is that it is an anachronistic and ultimately pointless exercise to attempt to assess Augustine's Christology either by the standard of Ephesus or Chaicedon. His thought is deeply rooted in traditional Latin forms. But it is just as true to say that he advances on those forms in a quite innovative way: firstly by approaching the incarnation as a complete Trinitarian actus, secondly by considerably developing the psychological model of the composite unity of Christ, and finally by applying his insights into the divine initiative of grace to the spiritual life of Christ.

In short, the so-called Antiochenism of Augustine is not a Syrian influence at all but a long-standing aspect of traditional Latin Christology. The story of how this came back, fully formed, into the East in the shape of Leo's Tome is well known. The Tome itself owed much to Augustine. ${ }^{38}$ It is significant that when this very independent Latin Christological tradition appeared on the agenda at Ephesus in $\mathbf{4 4 9}$ it so greatly disconcerted Dioscorus of Alexandria that he too, wrongly, thought that an Antiochene inspiration must have been at work.

\section{Notes}

1 Cf. G. Bavaua, 'Un thème augustinien. Le mystère de l'Incarnation', Revue des études augustiniennes, 9, 1963, pp.95-101; A. Piolanti, 'Il mistero del Cristo totale in s. Agostino', Augustinus Magister (Congrès internat. augustinien, Paris, Sept. 1954), vol.3, pp.453-469; E. TeSelle, Augustine the Theologian, London 1970, pp.146-156; G. Bonner, Christ, God and Man in the Thought of St Augustine (Deposito Libri, Angelicum), Rome 1984, pp.268-294; T.J. van Bavel, Recherches sur la Christologie de S. Augustin (Paradosis 10), Freiburg, 1954 (key work).

2 A. Dorner, Augustinus, Sein theologisches System und seine religionsphilosophische Anschauung, Berlin 1873, pp.87-107; A. Harnack, A History of Dogma (E.T.), London 1898, vol.5, pp.125-134.

3 Cf. Augustine, Enchiridion, 38; H.A. Wolfson, The Philosophy of the Church Fathers, London 1976, p.241.

4 O. Scheel, Die Anschauung Augustins über Christi Person und Werk, Tübingen 1901.

5 E. Portalié, A Guide to the Thought of St Augustine (E.T.), Chicago 1960; D.T.C., art. 'Augustin', Paris 1902. 
6 Cf. A. di Berardino (ed.) Patrology, vol.4, Westminster, Maryland 1986 (Turin 1978), ch.6, pp.342-462.

7 A. Trapè, in di Berardino (ed.), op. cit., p.430.

8 T. van Bavel (see note 1 ).

9 E. TeSelle, Augustine the Theologian, p.155.

$10 \mathrm{~J}$. McWilliam Dewart, 'The Influence of Theodore Mopsuestia on Augustine's Letter 187', Augustinian Studies (Philadelphia) 10, 1979, pp.113-132.

11 H.B. Swete (ed.), Minor Epistles of St Paul, Cambridge 1880-1882, vol.2, pp.293-297.

12 Confessions, 7, 25.

13 Cf. R.J. O'Connell, 'Alypius' "Apollinarism” at Milan', Revue des études augustiniennes, 13, 1967, pp.209f. Alypius states that he thought Apollinarism was the official Catholic Christology and on this basis he refused to subscribe to it. Only when his error was pointed out did he go forward to baptism. Many commentators, including Grillmeier, have consistenly misread this text and have presumed that Alypius was Apolinarist himself.

14 It is significant to note the connection between the Donatist crisis, which turned so much on the nature of the Church as the body of Christ, and Augustine's developing sense of ecclesial Christology in this period. The Donatists were put under an effective imperial proscription in 418, after which time Augustine's controversial writings are dominated by Pelagian matters. For an excellent brief review of the Donatist and Pelagian movements, see W.H.C. Frend, Saints and Sinners in the Early Church, London 1985, chs.5-6.

15 En. in Ps.27, 2.

16 Cf. R.V. Sellers, Eustathius of Antioch, Cambridge 1928.

17 Sermon 119. The same theme is found in Sermon 214 of the year 391, when he gave an elaborated Christology in the course of the liturgy, saying: 'A complete man, that is rational soul and body, was assumed by the Word in such a fashion as to be one Christ and one God, the Son of God; not the Word alone but the Word and the man, and this whole (totum hoc) is the Son of God the Father according to the Word, and the Son of Man according to the man ... . He is not only man but Son of God, but according to the Word by whom the man was assumed; and he is not only the Word but the Son of Man, but according to the man who is assumed by the Word' (Sermon 214, 6).

18 Explan. Ep. ad Galat., 27 (of the year 395).

19 Tertullian, Adv. Praxean, 37-38.

20 Persona una ex duabus substantiis constans; una in utraque natura.

21 Sermon 186.

22 H.M. Diepen, 'L' "Assumptus Homo" patristique', Revue Thomiste, 51, 1951, pp.573-608; 63, 1963, pp.225-245, 368-388; 64, 1964, pp.32-52.

23 De peccatorum meritis et remissione, 2, 17, 27.

24 Also elaborated in his early treatise, De ordine, 1, 24; 2,7,20.

25 Ep.187, 13, 38-41.

26 Ibid., 13,40.

27 J. McWilliam Dewart (see note 10), p.118.

28 For Augustine's knowledge of Gregory Nazianzen (in Latin tr.), see B. Altaner, Kleine Patristische Schriften (T.U., 83), Berlin 1967; and P. Courcelle, Les lettres greques en occident, 2nd ed., Paris 1948.

29 J. McWilliam Dewart, op. cit., pp.118f.

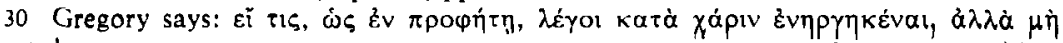

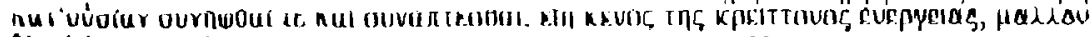

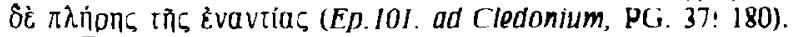

31 For further material on Augustine's use of 'person', see C.N. Cochrane, Christianity and Classical Culture, Pt.3, O.U.P. 1939; A. Outler, 'The Person and Work of Christ', in R.W. Battenhouse, ed., A Companion to the Study of St Augustine, O.U.P., 1955, pp.343-370.

32 Ep. $187,39$.

33 De consensu evangelistarum, 1,2,3. Augustine's use of the term 'person' is fluid, 
applying it in the old Latin legal sense of the lawyers and grammarians. He uses persona often to denote a function or office, as when he speaks of the angels as representatives of God in De Trinitate, 2,13, 23 and 3,10,19.

34 Enchiridion, 11,36.

35 (a) Theodore, P.G. 66: 981D-984A; Augustine, Ep. 187, 4,11; 5,16, CSEL 57:90,94:

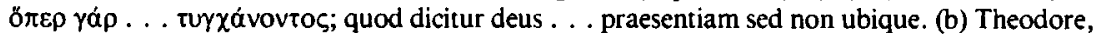

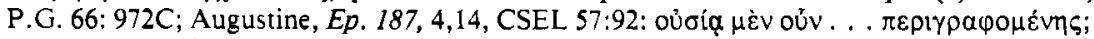
Sed sic est deus . . . ipso ubique totus. (c) Theodore, P.G. 66: 972D-973A; Augustine, Ep.

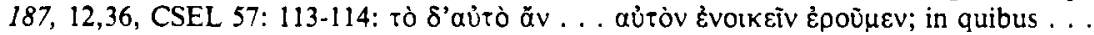
virtutis operatur. (d) Theodore, P.G. 66: 972BC-973B; Augustine, Ep.187, 5,16; 6,19; 13,38,

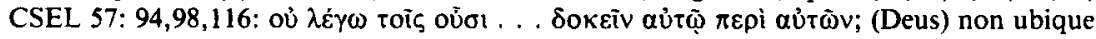
per . . . cui per gratiam benignus est et propitius. (e) Theodore, P.G. 66: 973B-976B; Augustine, Ep.187, 5, 17, CSEL 57: 94-95: ẳ cum igitur, qui ubique est . . . quanto fuerint caeciores. (f) Theodore, P.G. 66: 976B, 980C,

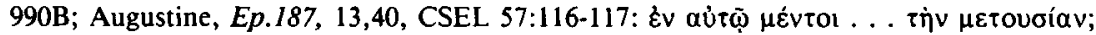
de ipso vero capite . . . dici potuit aut potest aut poterit. (g) Theodore, P.G. 66: 989D;

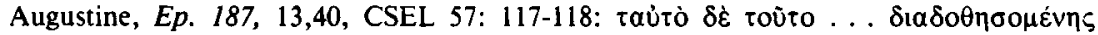

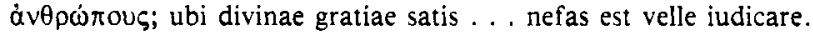

36 J. McWilliam Dewart, op.cit., p.119.

37 Cf. P. Hadot, Porphyry et Victorinus, Paris 1968; id., Adversus Arianos Marii Victorini (Sources chrétiennes, 69), esp. p. 712; M.T. Clarke, 'The Neo-Platonism of Marius Victorinus the Christian', in Essays in Honour of A.H. Armstrong, London 1981, pp. 153-159. The theme perhaps featured in the now lost 'Mixed Questions' of Porphyry, which Victorinus knew.

38 Augustine's devoted disciple Prosper of Aquitaine was, in 449, the secretary of Pope Leo. It was he who drafted the first version of the Tome (Leo, Letter 38, June 13, 449), building it up from Gaudentius of Brescia's Letter to Paul the Deacon and liberal doses of Augustine's Contra sermonem Arianorum (418): see C.R. Norcok, 'St Gaudentius of Brescia and the Tome of St Leo', Journal of Theological Studies, 15, 1913-1914, pp. 593-596; J. Gaidioz, 'S. Prosper d'Aquitaine et le Tome à Flavien', Revue des sciences religieuses, 22, 1949, pp.270-301. 